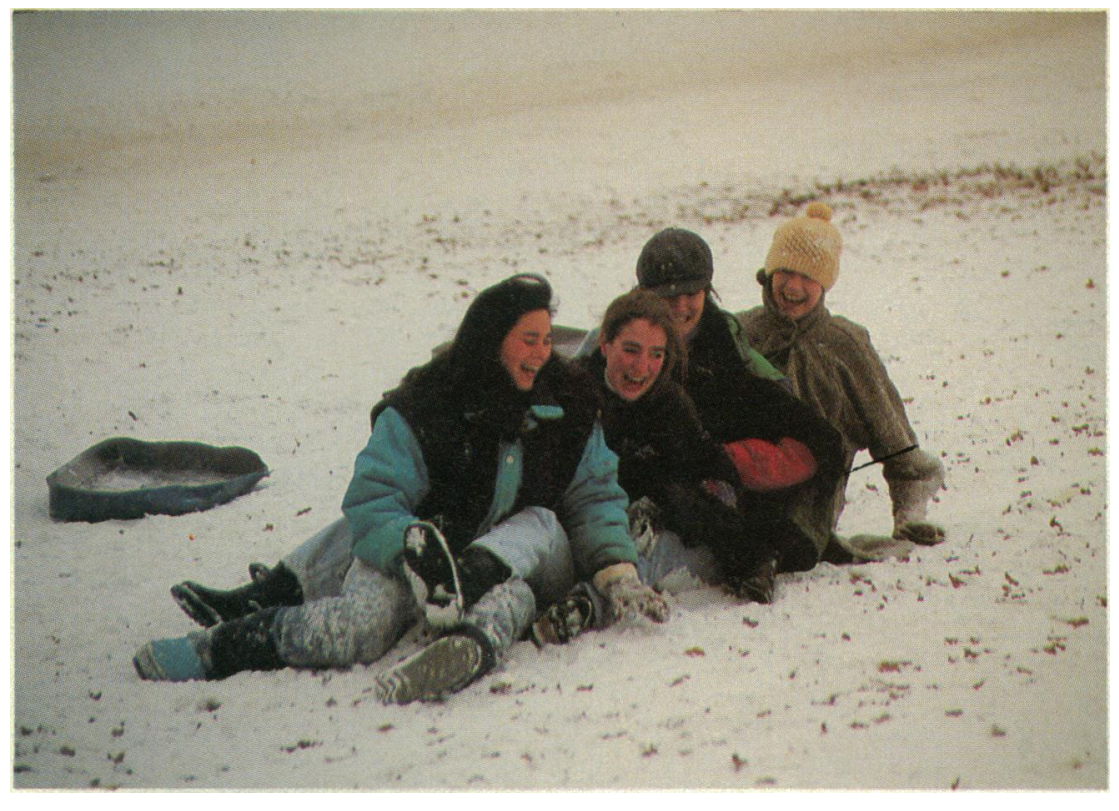

Makeshift sledges after social occasions can lead to an unhappy end to a holiday
Sledging can be compared with another high risk activity, motorcycle riding. The 1268 inpatients admitted over one year included 280 motorcycle drivers, among whom there were seven spinal injuries but no cases of paraplegia. ${ }^{5}$

When high speeds are achieved sledging is intrinsically dangerous. Even when compared with motor cycling it produces a disproportionately high number of cases of spinal injuries. Holidaymakers should be wary of participating in a social evening of sledging while on holiday.

I thank Dr H L Frankel, Mr I Nuseibeh, and Mr B P Gardner for allowing me to quote from their cases, and also Drs D Short and R Burr for their help in producing this paper.

1 Silver JR. Spinal injuries in sports in the UK. Br f Sports Med 1993;27:115-20. 2 Hedges JR, Greenberg MI. Sledding injuries. Ann Emerg Med 1980;9:131-3.

Kline DG, Lusk MD. Management of athletic brachial plexus injuries. In: Schneider RC, Kennedy JC, Plant MR, eds. Sports injuries: mechanisms, prevention, and treatment. Baltimore, Williams and Wilkins, 1985.

Sloan JP, Maheson $M$, Dove AF. How dangerous is sledging? $B M \mathcal{F}$ 1985;290:821.

Gissane W, Bull J, Roberts B. Sequelae of road injuries: a review of one year's admissions to an accident hospital. Injury 1970;1:195-203.

\title{
A commission of lunacy, mad doctors, and happy hunting
}

\section{B E C Gill}

History delighting to confuse us, the term "lunacy commission" has two quite different meanings. Lunacy commissioners were in many respects the forerunners of today's Mental Health Act commissioners. Appointed under various Georgian and Victorian acts of parliament, they had as their brief, among other things, to oversee institutions in which lunatics were kept to ensure that both public asylums and private madhouses treated their charges properly according to the regimes laid down by parliament, and to check that no patient was being inappropriately detained. If they found any such, they had powers of release.

Much less has been written about the other quite separate matter covered by the term commission of lunacy - namely, the legal proceedings taken against a person to relieve him of the conduct of his affairs or his liberty, or both, on the grounds of mental unfitness. The rough equivalent today would be an application to the court of protection. The novel Handley Cross by Robert Smith Surtees, published in 1854, contains a vivid account of such a legal case. It presents a complete contrast with present day procedures, being nothing short of a civil lawsuit fought along adversarial lines.

To understand the novel and this episode in it, it is necessary to know a little about the author. Although a London lawyer by training, Surtees was a countryman by birth. He was a member of the squirearchy and a foxhunter from childhood. His books reflect a tension between town and country. With the rise of a prosperous Victorian middle class and later "mushroom aristocracy," many newly wealthy people retired to the country. There they adopted attitudes to rural life and sports perceived by established locals such as Surtees to be entirely wrong headed.

The hero of Handley Cross is John Jorrocks, Esquire, Surtees's greatest creation and one of the great comic characters of English literature. Master of Foxhounds, the sporting wholesale grocer from the old City of London, he was created at least partly to satyrise these rural "yuppies" who went hunting in order to display their wealth and social status rather than, like Jorrocks and Surtees, because of their devotion to the sport for its own sake. Jorrocks was the very opposite of anything to be classed as smart. He was "not a gentleman" he was fat, not really able to ride, and ludicrously uncouth in social manners. But all Jorrocks's faults are forgiven, in Surtees's eyes, because of his down to earth, warmhearted character and his wholehearted passion for the chase.

Handley Cross is a long novel of 80 chapters, most of them about Mr Jorrocks's various adventures as master of the Handley Cross hounds. This position makes him one of the leading citizens of Handley Cross Spa, and much of the fun throughout the book comes from the outrages he perpetrates on the finer sensibilities of the more genteel and sanctimonious inhabitants. Jorrocks here personifies Surtees's own attitudes as a full blooded Regency man, delighting to lampoon the emerging priggishness and stifling respectability of Victorian times. Surtees realised his plan to create a character who would show up the changing scene of foxhunting, but then, like all good fictional inventions, Jorrocks took on a life of his own, with fantastic adventures of all kinds, including the one of present interest-his brush with the lunacy laws.

\section{The lunacy commission}

Trouble begins for our hero when Captain Doleful, the mealy mouthed master of the ceremonies at Handley Cross, buys a horse from Jorrocks, which he overworks, half starves, and generally mistreats. The horse falls sick and dies. Doleful sues Jorrocks for the return of the purchase money, and loses. A lawsuit between the two principal inhabitants of a major resort causes quite a stir.

The report of the action ... having done good service to the London papers during the dullness of autumnal news. . . Mr Jorrocks's conduct and career had been greatly canvassed by cautious citizens, amongst others by his next of kin, and we may briefly state that our worthy friend's jollities or eccentricities at length earned for him a commission of lunacy.

Jorrocks's family believe that the expense of hunting is
D B E C Gill, registrar in psychiatry 
unavoidably ruinous; in short, that $\mathrm{Mr}$ Jorrocks is in danger of wasting his entire substance on the pursuit of the fox. In fact, Surtees makes it plain that Jorrocks ran his establishment very economically, living well within his comfortable income.

After the necessary preliminaries, the Commission was opened in the long room of the Gray's Inn Coffee House, in Holborn [This may strike modern readers as a little odd, until they reflect that today's Mental Health Act Commission often sits in non-legal surroundings, such as a hospital] where the following highly respectable jury were sworn in to inquire into the merits of the allegation:

Mark Stimpson, Starch Manufacturer, Pimlico . .

John Cook, Pentonville, Milkman and Cowkeeper . . .

Thomas Boggon, Whitechapel, Nightsoilman.

With an incidental glimpse of a central London still full of tradesmen doing real work, and a note of Surtees's freedom to indulge in print a taste for lavatorial humour unthinkable even a few years later, let us take stock for a moment. Mr Jorrocks's family believe that he is mad and that because of his madness he is wasting all his money on hunting. According to the procedures of the time, they have brought an action in the civil courts called a commission of lunacy, which will look into the matter. Jorrocks has exercised his right to a jury and intends to defend himself. Thus we can be clear that our commission of lunacy is a court, with prosecution, defence, and a jury, under the direction of three commissioners (usually judges or senior barristers specially approved for the purpose).

The usual preliminaries having been observed, and silence obtained . . . and a proper time having elapsed, $\mathrm{Mr}$ Martin Moonface [the prosecuting counsel] rose with great solemnity.

"I do not know that I can call to my recollection," said he, "ever rising to address twelve honest Englishmen with such mingled feelings of gratification and regret as I experience at this present moment. ... Gratification, that I should have the advantage of so intelligent - so enlightened-so conscientious a jury . . . and regret-deep and poignant regret-that such a step as the present should be found necessary against so meritorious and amiable an individual as the unfortunate gentleman against whom a I now appear." Here Mr Martin Moonface heaved a heavy sigh, and looked at the back of his brief, on which was marked " 50 guineas."

"Believe me when I say that nothing but that high sustaining power, the moral consciousness of doing right, could induce me to undertake so thankless-so ungracious a task. No

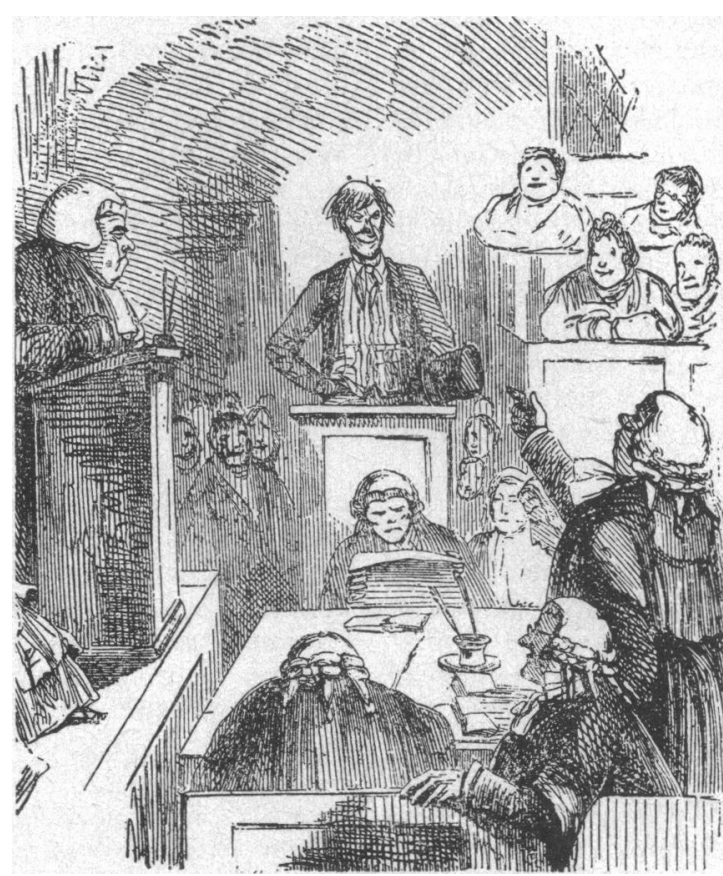

Fames Pigg, huntsman to $\mathrm{Mr}$ forrocks, gives the last piece of evidence in the case. Illustrations by Leech are from the 1854 edition of "Handley Cross; or, Mr Forrocks's Hunt" by Robert Smith Surtees feeling of personal ambition, no consideration of worldly aggrandisement could tempt $m e$ " [etc, etc].

We note that Moonface appears against Jorrocks, underlining once more the adversarial nature of the proceedings. Surtees's glee in lampooning a pompous member of his own profession is also striking. Although trained as a lawyer. Surtees never really worked as one. After serving his pupillage at Lincoln's Inn he bought a London practice that turned out to be worthless; he preferred poking fun at the law to practising it. Moonface goes on to make a long speech, making the "case for the prosecution," throughout which he plays most unashamedly to the gallery. "The long room was crowded to excess, and numerous auditors thronged every part of the house where hearing room could be obtained"-a legal case to try a person's sanity was a popular spectator sport.

The eloquence of Moonface's disquisition leaves no doubt of Surtees's narrative gift. Rumpole looks tongue tied by comparison. Moonface begins by introducing our hero's business life in the firm of Jorrocks and Co, tea dealers and grocers in the City of London, going on to aver that the "blameless tenor of his grocer's life is mixed up with a strong undercurrent of eccentricity, which has long been observable; and as the murmuring rill, strengthened by tributary streams, rolls on with growing force until its strength attracts the notice of the world and calls for measures to restrain the torrent of its impetuosity, so Mr Jorrocks's oddity has gone on increasing until the present inquiry has become absolutely and indispensably necessary."

Moonface goes on to give an account of $\mathrm{Mr}$ Jorrocks's hunting career, in as lurid and misleadingly sensational manner as he can. In doing so, he half inadvertently, half deliberately gets all hunting's special vocabulary wrong, finally referring to

"... large assemblies ... of fifty or sixty dogs_-"

"Ounds, you fool!" roared Mr Jorrocks, from the opposite side of the table. "Gentlemen!" exclaimed Mr Martin Moonface, in astonishment. "I call your attention to the unfortunate gentleman, I think his conduct might warrant closure of the business, even at this early stage ..."

Moonface's clever demonstration of Mr Jorrocks's short fuse where hunting is concerned is, however, not sufficient, and he proceeds to describe the principal "delusion under which the unfortunate individual suffers." Moonface clearly regards delusion as one of the main features of mental disorder, and the main way in which he seeks to establish that Jorrocks is deluded is by trying to show that his behaviour is abnormal. Clearly, this is far from modern psychiatric definitions of delusion ("a false, unshakable belief, inappropriate for the person's racial or social background"). Moonface does not inquire into whether Jorrocks's behaviour is actuated by false, unshakable beliefs but concentrates on the idea that his behaviour (he being a master of foxhounds) is intrinsically abnormal because it is inappropriate to his background (as a London grocer). In this he successfully appeals to the jury of other London tradesmen. ("Fancy me trotting round 'Ampstead 'Eath in a red coat with a pack of 'ounds at me 'eels!' says one, after they have retired to consider their verdict.)

Unsurprisingly Moonface does not follow modern psychiatric practice, but neither does he follow the legal usages of the time. The law recognised then as now that a person could be deluded but still capable of managing his affairs, provided that the delusions did not directly affect the business at hand and that other mental capacities were intact.

Moonface mentions that Jorrocks has not been to his office as much as formerly. This is a sure sign of ruin to the industrious members of the jury and is enough to convince them of Jorrocks' incapacity. But Moonface does not even try to show that Jorrocks's firm is being 


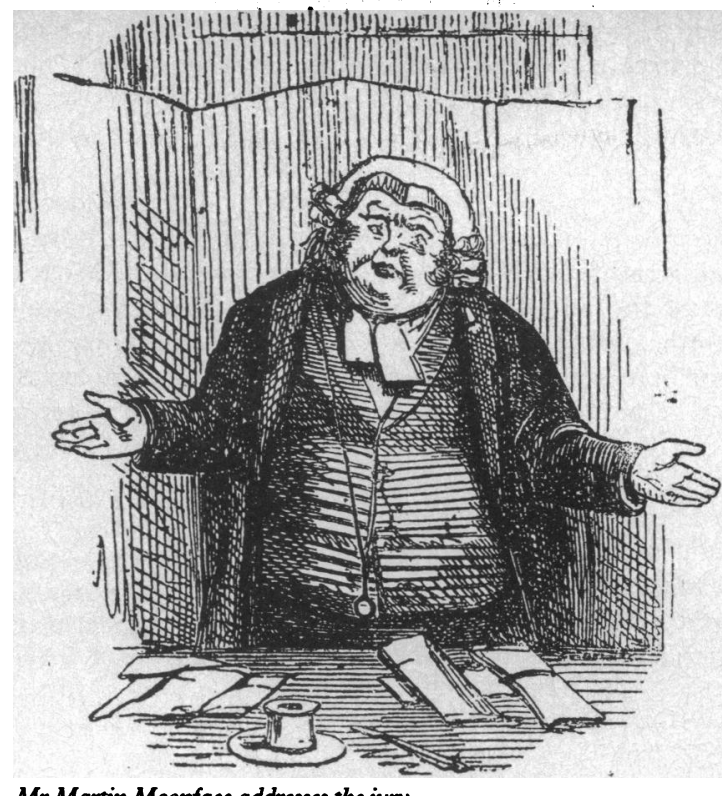

Mr Martin Moonface addresses the jury

affected by his hunting career. So he presents inadequate evidence that Jorrocks is deluded and that the alleged delusion is affecting his business, and thus presents no reason why, according to the law of the time, Jorrocks should be deprived of control over his affairs.

Although Jorrocks has a capable defence counsel, Moonface's eloquence about the alleged abnormality of our hero's behaviour carries the jury, which, after deliberating "more for the form of the thing than anything else" return a verdict of "insanity-adding that Mr Jorrocks had been incapable of managing his affairs since the day he took the Handley Cross Hounds."

\section{The madhouse}

We next find $\mathrm{Mr}$ Jorrocks confined in a private madhouse at Hoxton, a district of East London with a great concentration of such institutions. Surtees does not mention the link between the finding of mental incompetency by the court and Jorrocks's imprisonment, but it was not automatic that a person found incompetent should be compulsorily admitted: the general requirements of certification by physicians or a judicial order still applied.

Private madhouses admitted the wealthier patients, and asylums were for the poor. The regime to which Jorrocks is subject sounds comparatively humane. He is digging potatoes in the garden when visited by his friends to discuss an appeal against the verdict. He has been "deprived of his wig, but he had supplied its place with a red pocket handkerchief." This particular house is run by a physician referred to by Surtees as a "mad doctor," and his financial interest in Jorrocks remaining a patient is clear when the question of an appeal to the Lord Chancellor arises.

The "mad doctor" maintains that his patient is mad. "He had lucid intervals, certainly, but as soon as ever the subject of hunting was mentioned, off he went at a tangent." Jorrocks's friend Charles Stobbs replies that "he had seen many men that way," and the doctor's eyes glistened; "for he thought he'd like to fill his house with them: call it the United Foxhunters' Asylum, or some such name."

When his friends suggest that they would like Jorrocks to appeal, in the form of an interview with the Lord Chancellor, there are many protestations from the mad doctor "that the indiscretions of his friends would very materially retard, if not altogether prevent, $\mathrm{Mr}$ Jorrocks's recovery."
But

The solicitors at length agreed on requesting a private examination by the Chancellor, which was kindly vouchsafed....

Accordingly it was arranged that Mr Jorrocks should wait in his lordship's private room for the rising of his court. Thither our friend went, accompanied only by his partner, $\mathbf{M r}$ Simpkins, and Charley Stobbs. . . . The court sat late. His Lordship's train-bearer lent them a newspaper and, stirring the fire, advised them to sit round, and make themselves comfortable.

Accordingly they did.

Several people looked in on them;-a footman, an usher, a laundress, but nobody seemed inclined to stay.

Towards dusk a gentleman, with a singularly pleasing expression of countenance, who seemed more at home in the room than any of his predecessors had been, entered the room.

"Is Mr Jorrocks here?" asked he, after surveying the party by the fire.

"Mr Jorrocks is here!" replied our hero, getting up.

"Don't let me disturb you, pray," rejoined the gentleman bowing, and motioned Mr Jorrocks to be seated. Our friend, however, being up, took a coat-lap over each arm, and turning his back to the fire confronted the enterer.

"Coolish evening this, Mr Jorrocks," observed the gentleman, rubbing his hands as he approached the fire. "I hope your accommodation is comfortable at Hoxton?"

"Any thing but," replied Mr Jorrocks; "at least, I shall be werry glad to let you have it if you like. Can't even get a siedletz-pooder without an order from the Chancellor"....

"They feed you pretty well where you are, I suppose?"

"Tol-lol-mutton! mutton! toujours mutton, as we say in France."

"What! Mutton every day? Can you tell me how many legs a sheep has?"

"Dead or alive?" inquired $\mathrm{Mr}$ Jorrocks.

"They say you are mad about hunting, I understand," observed the gentleman after a laugh at Mr Jorrocks's acuteness.

"Ah-'unting's the thing"-exclaimed Mr Jorrocks-“"the sport of kings-but, however, never mind, we won't talk about that," added he, checking himself, and saying, "I wish the old gentleman would come."

The gentleman visitor is, of course, the Chancellor himself in mufti. By asking riddles (the answer to the number of legs on a sheep is alive; four; dead; two, the other two being "shoulders" when prepared for the table) and sensible questions about the state of the markets he tests Jorrocks's general competence and fitness as a man of business before our hero knows who he is talking to.

"Your lordship's carriage is at the door," announced a footman in undress livery.

"My vig!" exclaimed Mr Jorrocks, starting. "Have I been talking all this nonsense to the Chancellor? Oh, dear! oh, dear!" continued he, wringing his hands and stamping, "wot a confounded old jackass I am. Dash my vig! I don't think I shall ever grow wiser."

"Don't alarm yourself, my good friend," observed the Chancellor, mildly; "I am glad to have seen you in this way, for it has given me an opportunity of judging how you are. You may be an enthusiast; but, I think sir," turning to the doctor, "Mr Jorrocks seems perfectly able to do without your assistance, and I should recommend your letting him go home quietly from here." So saying, his lordship bowed and retired.

"Once his Lordship was out of earshot [Jorrocks] kicked out the mad doctor's hat crown, and politely placed the remains on his head." He then sets off home with his friends, expels the miserable Doleful, and takes possession again of what is rightfully his. Surtees did not make explicit the distinction between confinement and determination of competency during the account of the court case, and being released from 
confinement in a madhouse did not necessarily mean resumption of control over one's affairs, but this scene and the rest of the book make it clear that Surtees meant Jorrocks to be in full control again.

\section{Mental health law}

These few chapters vividly bring to life the two main strands of mental health law of the mid nineteenth century: determination of competency and compulsory admission. The legal case is about determining mental competency. The legal tests applied today in this area, which are governed not by statute but by case law, have changed very little since the end of the last century, though happily they are now applied in less adversarial settings. Regarding compulsory admission, the legal mechanisms are not made clear, but Surtees colourfully portrays the private madhouse system, less well known than the public asylums, and the unsavoury "mad doctor" with a direct financial interest in his patient's continued confinement.

Surtees's books contain many medical characters and stories. They share with Dickens the splendid illustrations of John Leech but they lack Dickens's sentimentality and deal with country life as well as town. Robert Smith Surtees has escaped widespread literary attention. Most of his readers today are not primarily "literary" at all, coming from the world of country sports where his books were set, yet he has much to offer a far wider range of readers, including anyone with an interest in the social history of medicine.

I thank Mr Peter Bartlett of the Wellcome Institute for the History of Medicine for his advice and encouragement, and Dr Catherine Oppenheimer. Some of Surtees's books are available in paperback, and all are obtainable in splendid facsimile editions from the R S Surtees Society, Thacker's Cottage, Nunney, Bath BA11 4NP.

\title{
A Christmas tale
}

\author{
Graham M Hunter
}

It was late afternoon on Christmas Eve and blowing a gale. The wind drove a flurry of snow against the car windscreen as it whipped up the white horses out in the English Channel.

No wonder I had been summoned to visit George. Something had gone wrong with his daily dip in the ocean and he was said to be suffering from exposure.

George, now 86 , was in his quiet way a character. $\mathrm{He}$ had been a builder, and I remembered how tenderly he had nursed his dying wife to the end. Since then he had befriended numerous neighbours, helping them with burst pipes and other disasters. But mainly he had devoted himself to a society for the blind and over the years he visited several members on a regular basis. "I get on well with blind people," he said, "on account of looking after my uncle who was blinded in the great war."

George's great delight was his daily swim in the sea.

Bexhill on Sea, East Sussex TN40 2NH

Graham M Hunter

Every day of the year, no matter how cold the weather, George could be seen taking his dip, deterred only by

BMF 1993;307:1606

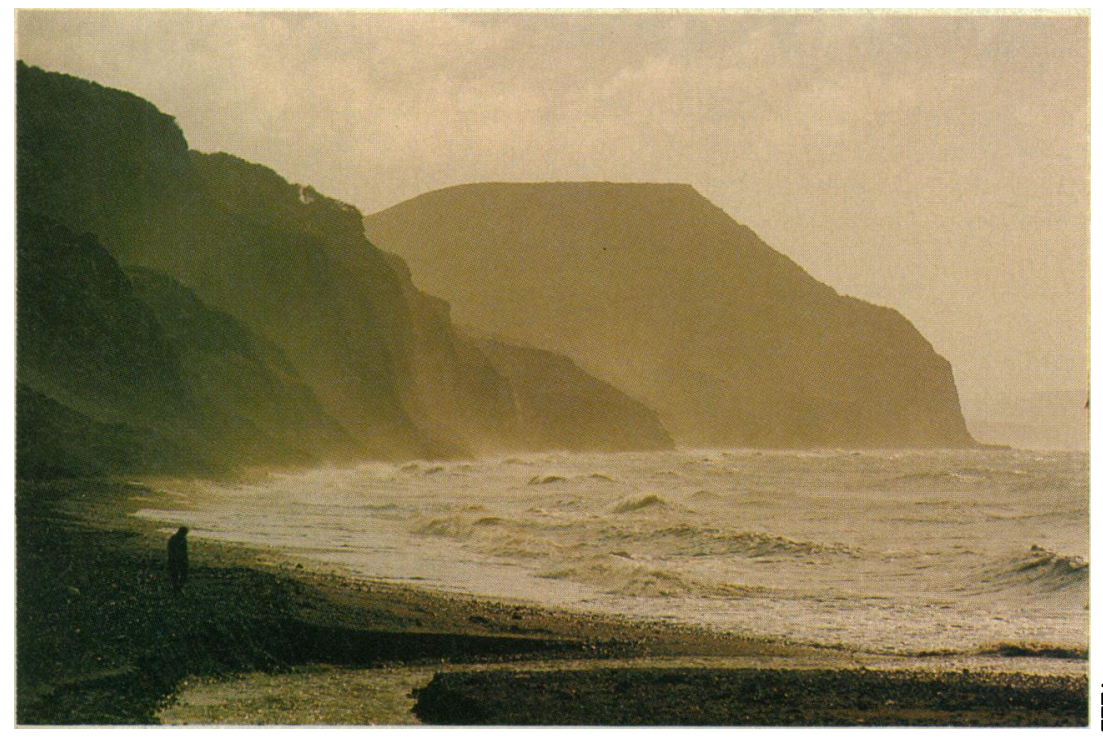

Adverse weather could not deter George from taking his afternoon swim severe storms. As I drove to the farm I mused that this activity could prove to be his undoing.

Despite his age, George was mentally and physically fit. He sailed through the elderly driver's medical and I had no hesitation in signing him up. How sad that he should be meeting his end.

I reached the rather isolated farmhouse where he was spending Christmas with his married daughter. "It would have killed a lesser man," she related as she led me upstairs. Accustomed to reviving half frozen lambs on the farm, she had put him in a hot bath and tucked him in a warm bed with a mug of cocoa. George was now recovering, and after a brief examination I sat down as he slowly related his remarkable story.

Even though the sleet was turning to snow, nothing could deter him from taking his afternoon swim. Away from his usual bathing beach, he decided to visit an isolated cove down a rough track over a mile from the farm. As usual, he drove himself to the beach, where there was a shelter in which he would change.

Unfortunately the shelter was locked up for the winter, and as he didn't relish changing in the car he looked around and spied a steel cabin, set up for disabled users, its door swinging in the wind. Thankful for its shelter, he changed, slammed the door, and, so hardened to the adverse conditions, enjoyed a refreshing bathe. On his return to the shelter, to his horror, he could not open the door. "A cold fear settled on me, doctor. My clothes and car keys were shut inside, even my towel. I knew I'd never make it down that track and I was already really chilled. What would you have done?" A keen swimmer myself, I was stumped.

George continued: "It was all I could do to get back to the car when suddenly I remembered a blind friend giving me one of those magnetic affairs to hide a spare key under the bodywork. I'd used it really to please him and expected it to fall off. In fact I'd forgotten about it till that moment."

With frozen fingers, George had found the key, dug out an old mac from the boot, and just managed to reach the farm.

By the time I went downstairs, it was $6 \mathrm{pm}$. Now off duty, I was only too happy to join the family in a glass of hot punch as we drank to the health of a remarkable old patient. 